\title{
Collaborative Teaching
}

\author{
Wan Nurhasyimah W. Mohd Apandi, Mohd Daud Abdul Rahim \\ Faculty of Art \& Design, Universiti Teknologi MARA, Perak Branch, Seri Iskandar Campus, Seri \\ Iskandar, 32610 Perak, Malaysia \\ Authors'email: wansyima86@gmail.com,daudraahim73@gmail.com
}

Published: 28 September 2020

\begin{abstract}
Collaborative teaching methods is related with Pedagogy theory in academician achievement as team members (Armstrong (1977); cited in David Nunan (1992)). The definition of collaborative teaching approach is known as team teaching in classrooms practices, with a group of creative thinkers to brainstorm about ideas or other creative problems. This practice should be done continuously to be effective. However, there are some challenges that educator will face when practicing collaborative teaching in classroom. The challenges include clash of teaching hours, misconducting time management for students, percentage of rubric assessment, and confusion in terms of differing opinion from educators. Collaborative teaching also known as team teaching is an approach to educate students with two or more teachers in the classroom for a same subject (Robinson et al., 1995).
\end{abstract}

eISSN: 2550-214X (c) 2020. The Authors. Published for Idealogy Journal by UiTM Press. This is an Open Access article distributed under the terms of the Creative Commons Attribution-NonCommercial-NoDerivatives License (http://creativecommons.org/licenses/by-nc-nd/4.0/), which permits non-commercial re-use, distribution, and reproduction in any medium, provided the original work is properly cited, and is not altered, transformed, or built upon in any way.

\section{METHOD OF COLLABORATIVE TEACHING}

Implementation of collaborative teaching among the lecturers in the Faculty of Art and Design, Department of Fine Art, UiTM Technology MARA was conducted for each subject by two lecturers. Collaborative teaching is one of the methods that can promote and improve the learning outcomes where the students must achieve the outcome after all finished topics are taught (Benjamin (2000) and Tomei et al. (2012). As a good educator, we should enhance teaching skill and try to adapt the collaborative teaching in the classrooms along with other educators. Aspects of collaborative teaching in classroom practices are very important to students. Lecturers have to understand the student's needs by delivering understandable info and knowledge when teaching them. In this era of technology, application of technology and gadgets are very important to help students interact more in classroom practices.

Some suggestions on how to overcome the challenges included methods that encourages and enables student to pay attention and concentrate in class, where there is collaborative teaching in session. One of the approaches is the visual teaching and learning by way of using slides and videos. With this kind of approach, it will be easier for students to visualize all of the information given. For instance, by using dynamic fonts, images, and sentences to explain information, students will readily understand the information given because visual images in slides could encourage students to understand and relate to the subject.

Collaborative Teaching is the right method of application, in conjunction with the collaboration between senior and co-lecturer, which in turn could facilitate students in understanding the learning processes even more effectively. According to Jennings (2012), working effectively in Collaborative Teaching will facilitate the development of new knowledge and skill, which in turn can encourage students to easily learn something new and sharpen their skills in theory and technical skills in part with the lecturers.

In terms of preparation for teaching materials with teaching partner, we decided to combine our materials and notes to share with the students in the classrooms, as per discussed. Collaborative visual 
teaching by using slides, videos and illustration are one of the mediums to be used, especially in studio and lab works whereby the lecturers will demonstrate the procedures and provide the samples as guidelines. This collaborative approach is intended for studio project and the idea was to use presentation slides for them to easily understand the learning process in their respective classrooms. Richards and Nunan (1990) cited that collaborative teaching by lectures and colleagues would have an effect on the audience. All lecturers must be prepared with a complete preparation of teaching technique and skills to be applied in their classroom practice. Sharing personal teaching experience, observation, and critique session in classrooms practice will also help the learning process.

Besides collaborative teaching with other educators, Internet could also be a good source for students in a classroom. Internet has a lot of application that could be utilized as a method of collaborative teaching such as Facebook, Blogging sites, YouTube, Whatsapp and Telegram. It is also a medium of communication in teaching that could help provide notes to students so that they will be better prepared earlier before class and is also part of UiTM's blended learning program. By using this approach, student will be alerted on class updates and new information regarding specific subjects. The students will be able to receive up-to-date information from lecturers as part of their learning process.

In a collaborative teaching method, educators will definitely give full attention and effort to help students in giving them the best lesson in technical and theoretical practice, during and beyond lecturing hours. By adapting this collaborative teaching method student will also have a good teamwork in classroom practice. In addition, collaborative team teaching helps a lot In terms of training the students in a group to be more effective in their classroom. Collaborative teaching group is very important because the activities and task could be adapted to the students' skills and abilities. It is also to make sure that the work is relevant to the students' project outcome.

The final assessment that has been conducted by team teaching lecturer for the subject are to combine the marks; and the marks given are based on the percentage of assessment rubric. The students' assessment rubric is used to measure the relevance of an artwork, personal knowledge about content, research, idea, style, theme, technique, creativity and expression. Assessments are also based on rubric template and the percentage will be divided among the first and second assessor. According to Steven and Levi, (2005), In collaborative teaching, rubric assessment will help student to make progress in learning and to submit their assignments on time. Students will develop their own awareness in their learning process or artwork progression. In this situation, lecturers could refine their teaching skills by evaluating the assessment course as a result of collaborative teaching.

There is another approach in collaborative teaching method where the class could organize a professional art talk with links to the industry. This program will invite fine artists or gallery curator to share their knowledge and experience in terms of the reality in their respective industries. It will open opportunities for students to choose their profession either as designer, artist, curator, writer or something else. Besides that, they could venture into possible business collaboration with the business related to arts and interior decoration like painting, sculpture, printmaking and drawing. This professional art talk is important to all students because they will be more aware about Malaysian art scene, especially in the field of art appreciation. Moreover, this kind of collaborative teaching method could lead students to produce brilliant idea in classroom practice so that the idea and theme can be an approach for student to experience the feel of artwork production as an artist.

Villa, Thousand and Nevin (2004) stated that collaborative teaching is a form of pedagogical method; an effective collaborative team teaching, therefore, should focus on professional development activities, which are structured around collaborative planning and team-teaching models. Through the exposure from industries by professional art talk program that had been conducted, some of the art exhibition has already included UiTM students such as PETRONAS Gallery, Bank Negara Gallery, $U O B$ Gallery and Segaris Art Centre Gallery. In the classroom, the aim in collaborative teaching is to encourage the students in knowing that they could earn a living from art and if they are creative, and that their artworks could be in demand by art galleries and collectors from both Malaysia and 
International. Most of the time, student's confident level is very low, which is why educator should implement new strategies or methods.

Furthermore, in classroom practice, presentation is the best method for the students to present their own perception and ideas about the issue, and all members could give full commitment and focus in teamwork. It also will help them express their critical thinking on the subject, reference, and their ideas if students are to participate and give full cooperation in fulfilling a collaborative teaching method. The collaborative learning task must ensure that every group member adapt something from their discussion and presentation.

\section{CONCLUSION}

In conclusion aligning with the demands and competitions, an educator needs to prepare new teaching tools along with the enhancement of technology in team teaching. It would have to make use of the relevant tools from open media and make use of websites, storyboards, hardcopy notes, slides presentations, and group chats instead of the usual teaching practices. In addition, the gallery visits, attending talks, questions and answer sessions and project works are also important to enhance students' creativity and ideas in a collaborative teaching class. Perez (2012) stated that collaborative teaching creates a stronger relationship between senior lecturer, co-lecturer and the students and can be improved in terms of more flexible attitude, willingness to embrace new ideas and to be able to adapt with circumstances.

\section{REFERENCES}

Benjamin, J. (2000). The scholarship of teaching in teams: What does it look like in practice? Higher Education Research and Development, 19(2), 191-204.

David Nunan (1992), Collaborative Language Learning and Teaching. Cambridge University Press

Katherine D. Perez (2012), The Co-Teaching Book of Lists. John Wiley \& Sons

Matthew J. Jennings (2012) Teaching for Results: Best Practices in Integrating Co Teaching and Differentiated Instruction. R\&L Education

Nunan, David (1991): Language Teaching Methodology. Hemel Hempstead: Prentice Hall.

Richards, C. (2005): "The design of effective ICT-supported learning activities: exemplary models, changing requirements, and new possibilities". Language Learning and Technology 9(1): 60-79

Robinson, B., \& Schaible, R. M. (1995). Collaborative teaching: Reaping the benefits. College Teaching, 43(2), 57-59.

Tomei \& Lawrence A. (2012), Learning Tools and Teaching Approaches through ICT Advancements. IGI Global 
Idealogy Journal

Volume 5 Issue 22020
溇: IDEALOGY

JOURNAL 